\title{
Building Attendance Application with Location Based Service Technology and Waterfall Method to Overcome Long Attendance Queues and Reduce The Risk of Exposure to Covid-19
}

Research Article

\author{
Rendi Fajrianto $\mathbb{B}^{1 *}$, Masmur Tarigan $\left(\mathbb{D}^{2}\right.$
}

1. Faculty of Computer Science, Esa Unggul University, Jakarta 11510, Indonesia

2. Faculty of Computer Science, Esa Unggul University, Jakarta 11510, Indonesia

*rendifajri@student.esaunggul.ac.id (coresponden author)

masmur.tarigan@esaunggul.ac.id

\section{ABSTRACT}

Employee attendance using finger print attendance device, is not efficient enough for PT. Modern Gravure Indonesia, because it will result in long queues. In addition, attendance using a finger print attendance device can increase the risk of contracting COVID-19 disease, because there is physical contact. So a mobile-based application is needed in order to anticipate long attendance queues and avoid the risk of being exposed to COVID19. This application provides an attendance feature with location validation using LBS technology. If the employee is already in the office area or less than 500 meters from the office coordinates, then he or she can take attendance, so the employee cannot commit fraud. This application can also display monthly reports that are used for integration with the PT. Modern Gravure Indonesia. The method used to build this application is Waterfall and UML diagram modeling. This application will be built using the Flutter framework. And for the server side it will be built using the Laravel framework. The result of this research is to create an application that is able to overcome long attendance queues and reduce the risk of being exposed to Covid-19 at PT. Modern Gravure Indonesia.

Keywords : Attendance, mobile application, LBS, waterfall, Covid-19.

Journal of Intelligent Computing and Health Informatics is licensed under a Creative Commons Attribution-Share Alike 4.0 International License (CC BY-SA 4.0). 
(c) (1) (2) 


\section{INTRODUCTION}

In a company, employee attendance is one component that affects the employee's salary, if an employee is late, his salary will be deducted. Employees who are 1 to 60 minutes late will have their salary deducted by 1 hour. If the employee is 61 to 120 minutes late, his salary will be deducted by 2 hours. The salary deduction is expected to make employees more disciplined.

PT. Modern Gravure Indonesia is a leading flexible packaging manufacturer, based in Serang (Masmur \& Alfarisi, 2020). This company has 293 employees. Working hours at this company are from 08.00 to 16.00 from Monday to Friday and 08.00 to 13.00 for Saturday.

At PT. Modern Gravure Indonesia, attendance is done using a finger print attendance device. The attendance device is placed in the main hallway in the office. When approaching office hours or leaving office hours, many employees will take attendance, causing queues to pile up.

The problem is, attendance using a finger print attendance device can increase the risk of contracting the COVID-19 disease, because there is physical contact. Considering the number of positive cases in Indonesia continues to increase, as of May 31, 2019, a total of 1,821,703 and 50,578 cases of death (covid19.go.id) were recorded. Finger print attendance machines can be a place for the COVID-19 virus to nest. "According to the Head of the Semarang City Health Office, Abdul Hakam, from the results of the investigation, employees who were infected with Covid-19 during their absences touched their fingers to the fingerprint scanner" (Aji, 2020).

To overcome this problem, a mobile-based attendance application will be built with the title "Designing Attendance Applications With Location Based Service Technology and Waterfall Methods to Overcome Long Attendance Queues and Reduce the Risk of Exposure to Covid-19".

With this application, it is expected to be able to eliminate piles of employees when doing attendance. This application also uses Location Based Service (LBS) technology as location validation (Sri et al., 2020). Location Based Service (LBS) is a service that is used to find out the position of the user, then use that location information. If the employee is already in the office area or 500 meters from the coordinates of the office, then he or she can take attendance, so the employee cannot commit fraud (Jithesh et al., 2016).

The recommended location for taking attendance is in the main hallway of the office. Because in that area, it is definitely within the specified radius for attendance or less than 500 meters from the coordinates of the office, and in that area the office wifi network is covered. This application is able to run if the user's device is able to access the internet. The attendance radius is determined to be 500 meters, because sometimes there are mobile devices that have low location accuracy, so the radius distance tolerance is given.

In this application, there is also a feature for making monthly attendance reports that are used for integration into the PT. Modern Gravure Indonesia. This report contains the Employment Identification Number (NIK), the name of the employee as well as information on the length of working hours, overtime hours and late hours. Information on the length of working hours affects employee salaries, as well as the length of overtime and late hours, where if an employee is overtime, the salary will be added to overtime allowance, and if an employee is late, the salary will be reduced by a late deduction.

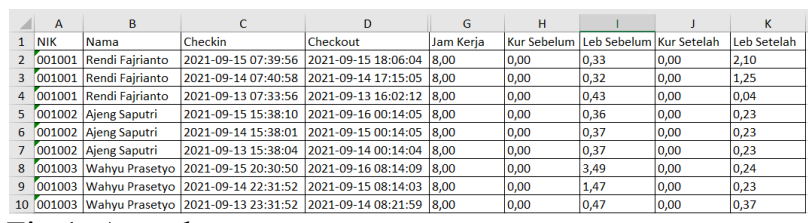

Fig 1. Attendance report.

This application is built using the Flutter framework (Alessandro, 2019). This application will access data from the API server, which includes being able to perform attendance, view attendance data and view attendance reports for each employee. And for the backend side of the API provider, this application will be built using the Laravel framework (Suryono, 2020).

\section{LITERATURE REVIEW}

\subsection{Attendance}

Attendance or attendance card is a document that records the attendance hours of each employee in the company. The attendance record of the employee can be in the form of a regular attendance list, or it can also be in the form of an attendance card filled in with a timekeeping machine. The work of recording time can basically be separated into 2 (two) parts, namely attendance time keeping and shop time keeping (Maulidyah, 2019).

The presence of an employee is important because it can be said that someone has not been able to manage his time well if someone is often late (Leon et el., 2020).

Each employee must register his attendance by filling out the attendance list at the designated place. Attendance must be recorded by the employee concerned.

\subsection{Previous Study}

There are several previous studies that have been proposed related to the topics raised in this research. The (Putra et al., 2019) proposed the lecturer attendance is Android Based Lecture Attendance application case study of Fakultas Ilmu Komputer dan Teknologi Informasi (FKTI) at mulawarman university. When attendance takes the coordinates of the device. There is location

J Int Comp \& He Inf. @JICHI 2021 https://doi.org/10.26714/jichi.v2i2.8474 
validation, if the user is already at the location, then the user can make attendance. Waterfall development method. Features for lecturers open session, close session. The technology used is Java android, PHP, MySQL.

The same of topic was also proposed by (Pribadi \& Setiyawati, 2021) that proposed student attendance application is Location Based Mobile Attendance Application (named AbsenLoc). When company attendance application the attendance takes the coordinates of the photo for location validation, if the user is already at the location, then the user can make attendance. There is validation of the selfie location. Research and Development methods. There is a web page with features for managing event data and member data. The technology used is Java android, Fire store.

The company attendance also by (Dayumi et al., 2018) that proposed Location Based Services (LBS) Employee Attendance System Using the Android Platform. When attendance takes the coordinates of the device is location validation, if the user is 200 meters or less from the company's location, the user can take attendance. The System Development Life Cycle (SDLC) development method. There is a web page with features for managing employee data, department data, leave. The technology used is $\mathrm{CH}$.

\section{PROPOSED WORK}

The proposed system is a mobile-based application that provide attendance feature. With this application, it is expected to be able to remove long queues employee and reduce the risk of exposure to Covid-19 when doing attendance. This application also uses Location Based Service (LBS) technology as location validation (Sri et al., 2020). Location Based Service (LBS) is a service that is used to find out the position of the user, then use that location information. If the employee is already in the office area or 50 meters from the coordinates of the office, then he or she can take attendance, so the employee cannot commit fraud (Jithesh et al., 2016).

The recommended location for taking attendance is in the main hallway of the office. Because in that area, it is definitely within the radius specified for taking attendance or less than 50 meters from the coordinates of the office, and in that area the office Wi-Fi network is covered. This application is able to run if the user's device is able to access the internet.

In this application, there is also a feature for making monthly attendance reports that are used for integration into the PT. Modern Gravure Indonesia. This report contains the Employment Identification Number (NIK), the name of the employee as well as information on the length of working hours, overtime hours and late hours. Information on the length of working hours affects employee salaries, as well as the length of overtime and late hours, where if an employee is overtime, the salary will be added to overtime allowance, and if an employee is late, the salary will be reduced by a late deduction.

This application is built using the Flutter framework (Alessandro, 2019). This application will access data from the API server, which includes being able to perform attendance, view attendance data and view attendance reports for each employee. And for the backend side of the API provider, this application will be built using the Laravel framework (Suryono, 2020).

This application has attendance feature that uses LBS technology, so this can avoid attendance fraud. This application also has import employee feature, so the user can input all employee. This application has export attendance feature, so the user can use it as an attendance data that can affect payroll data.

\section{METHOD}

In this method, information is obtained from various references to books and journals that already exist. In addition, information is needed to deepen knowledge by searching for information from other websites.

\subsection{Qualitative Research}

The approach used in this study is a qualitative research. Qualitative research is research that does not use calculations or is termed scientific research that emphasizes the natural character of data sources. According to Sukmadinata, qualitative research is a research aimed at describing and analyzing phenomena, events, social activities, attitudes, beliefs, perceptions, thoughts of people individually and in groups.

The location of the research implementation is at PT. Modern Gravure Indonesia, having its address at Jalan Modern Industri XVI Blok AG No. 8 Cikande Modern Complex, Serang, Banten 42186, Telephone: (0254) 7950261 starting on April 1, 2021.

Several data collection methods are carried out to obtain information that will be used in the process of designing and building this system, including the following:

1. Survey. In this method, direct survey activities are carried out at PT. Modern Gravure Indonesia located in Serang - Banten. This research was conducted to obtain relevant data according to research needs.

2. Literature studies. In this method, data mining and information collection are carried out from books, journals, final assignments and relevant articles. Literature studies are also carried out by accessing websites to obtain additional information. By extracting data from various sources, more complete information can be obtained, because the information is obtained from different perspectives.

Analysis of the current system is carried out based on the information obtained. In the old system, employees did attendance on the attendance machine at the PT. Modern Gravure Indonesia. The attendance device is placed in the main hallway in the office. When approaching office hours or leaving office hours, many employees will take attendance, causing queues to pile up. In addition, attendance using a finger print attendance device can increase the risk of contracting COVID-19 disease, because there is physical contact.

\subsection{Waterfall}

The development method for this application uses the Waterfall method (Charles, 2015). In Waterfall there are 
several phases including (Ahmed et al., 2016):

- Requirements. At this stage, it will collect the requirements needed in making the system to be built. From the requirements obtained, analysis is carried out to build a new system based on the needs scenario.

- Design. At this stage, the interface design modeling is used to describe the system to be created.

- Implementation. After the design and data collection is complete, the system will be built directly using Visual Studio Code as a Code Editor, Flutter framework for mobile applications and Laravel PHP framework for API provider backend. At this stage also be checked against the program code implemented.

- Verification. This stage is the testing stage of the system that is made so that the system can run properly. If at this testing stage the system created has problems, it will return to stage 7 , namely Program Coding for repairs.

- Deployment. At this stage, the system will be implemented or installed on the user side.

- Maintenance. At this stage will be the maintenance of the system already built.

\subsection{Unified Modeling Language}

For the design using UML diagrams. The Unified Modeling Language (UML) is a language to describe the system in a visual form. UML was created with the aim of describing the modeling and objects of the system (Bhuvan, 2017).

In UML there are diagrams which include the following (Ajit, 2019):

- Use Case Diagrams describe the relationship between users and system features

- Class Diagram describes the class structure on the system along with the attributes and status of these classes and attributes

- Sequence Diagram describes the order of the flow of functions in the system

- Activity Diagram describes a series of user activity flows on the system

The survey method used is interview. With the interview method, the needs and data to be used can be obtained. This can also be used to fulfill the Requirements phase of the Waterfall method.

\subsection{PIECES Analysis}

The analysis is carried out to analyze the employee attendance system, in order to identify the cause of the problem using the PIECES (Performance, Information, Economic, Control, Efficiency, Service) method.

\section{Performance}

Table 1. PIECES performance.

\begin{tabular}{lll}
\hline No & Factor & Analysis Result \\
\hline
\end{tabular}

\begin{tabular}{lll}
\hline No & Factor & Analysis Result \\
\hline 1. & Throughput & $\begin{array}{l}\text { The attendance data generated } \\
\text { by the attendance machine is in } \\
\text { the form of excel. Sometimes the } \\
\text { attendance data does not match } \\
\text { the format, thus requiring the } \\
\text { personnel officer to confirm it } \\
\text { manually. }\end{array}$ \\
& $\begin{array}{l}\text { The time required to perform a } \\
\text { relatively long absences. In } \\
\text { addition, sometimes there are } \\
\text { Time } \\
\end{array}$ & $\begin{array}{l}\text { employees who fail to make } \\
\text { attendance, so they have to } \\
\text { repeat it. }\end{array}$ \\
&
\end{tabular}

\section{Information}

Table 2. PIECES information.

\begin{tabular}{cll}
\hline No & Factor & Analysis Result \\
\hline 1. & Accurate & $\begin{array}{l}\text { The results of the data output on } \\
\text { the employee attendance machine } \\
\text { sometimes do not match the } \\
\text { format. }\end{array}$ \\
\hline 2. & Used & $\begin{array}{l}\text { The attendance process is less } \\
\text { efficient due to the limitations of } \\
\text { slow devices, unable to serve the } \\
\text { many employees who attend } \\
\text { attendance at one time. }\end{array}$ \\
\hline
\end{tabular}

3. Economic

Table 3. PIECES economic.

\begin{tabular}{ll}
\hline Factor & Analysis Result \\
\hline Efficiency & $\begin{array}{l}\text { The attendance process is less efficient, } \\
\text { because it takes a long time, resulting in } \\
\text { queues piling up. And staffing officers } \\
\text { must improve the attendance data } \\
\text { format. }\end{array}$ \\
\hline
\end{tabular}

4. Control

Table 4. PIECES control.

\begin{tabular}{ll}
\hline Factor & Analysis Result \\
\hline Data & There is no validation for employees \\
Security & who forget to attend attendance, thus \\
& harming employees.
\end{tabular}

\section{Efficiency}

Table 5. PIECES efficiency.

\begin{tabular}{cll}
\hline No & Factor & Analysis Result \\
\hline 1. & $\begin{array}{l}\text { Resource } \\
\text { Usage }\end{array}$ & $\begin{array}{l}\text { There is no dashboard of } \\
\text { information sources regarding } \\
\text { attendance, which is able to display } \\
\text { attendance data for each employee. }\end{array}$ \\
\hline 2. & Result & $\begin{array}{l}\text { The data from the attendance } \\
\text { machine output sometimes does } \\
\text { not match the format. }\end{array}$ \\
\hline
\end{tabular}


6. Service

Table 6. PIECES Service

\begin{tabular}{lll}
\hline No & Factor & Analysis Result \\
\hline 1. & Service & $\begin{array}{l}\text { There is no system that provides } \\
\text { fast attendance so as not to create } \\
\end{array}$ \\
& & long attendance queues.
\end{tabular}

\section{RESULT AND DISCUSSION}

At PT. Modern Gravure Indonesia, attendance is done using a finger print attendance device. The attendance device is placed in the main hallway in the office. When approaching office hours or leaving office hours, many employees will take attendance, causing long queues.

\subsection{Use Case}

The design of this application requirement is described in the Use Case Diagram.

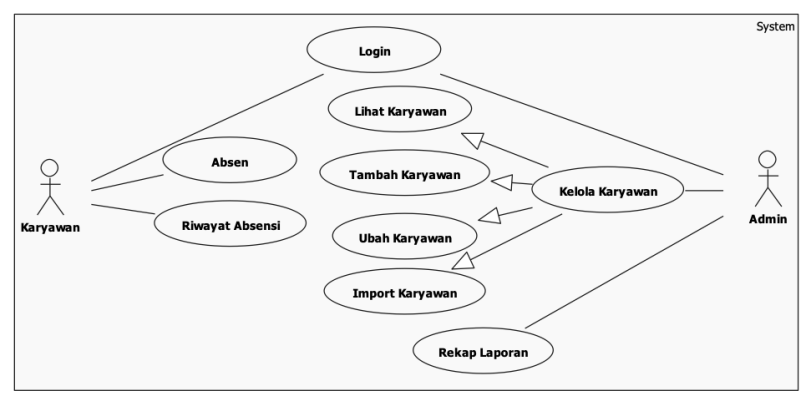

Fig 2. Use case.

On the employee menu, there is a menu for attendance and viewing attendance history. On the admin menu, there is a menu to manage employee data and view reports.

\subsection{Activity diagram}

The design of a series of absent function activities is described in the Activity Diagram.

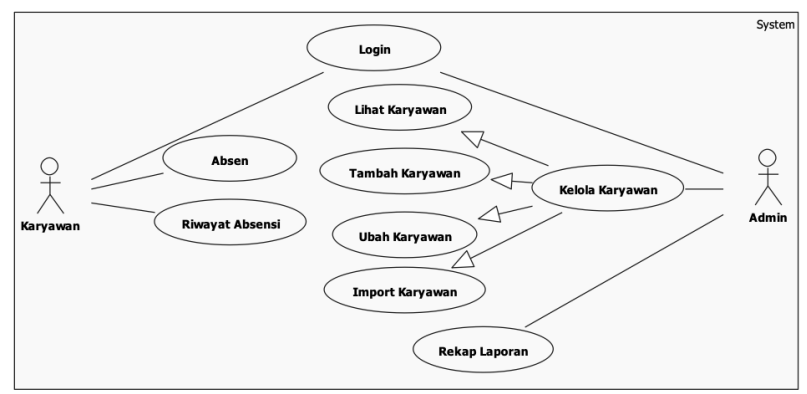

Fig 3. Activity diagram.

In the attendance menu, employees press the Check In or Check Out button. Then the application will get the location coordinates of the employee's device. Then the application will access the absent API by sending the employee NIK and location coordinates. If attendance fails, an error message will appear. If the attendance is successful, then the attendance data will be entered and the application will display a successful message.

\subsection{Class Diagram}

The design of these application classes is described in the Class Diagram.

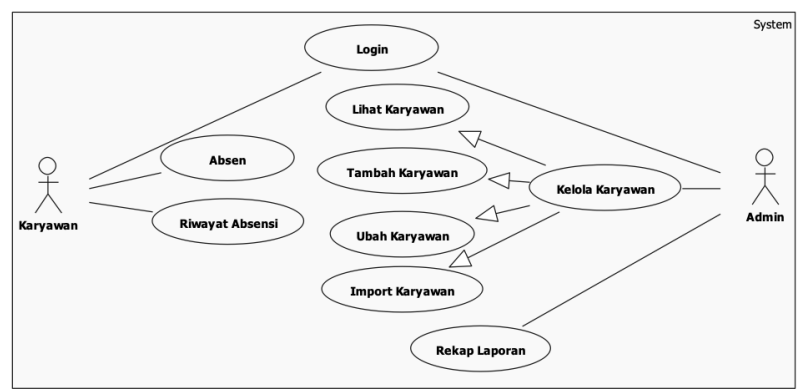

Fig 4. Class diagram.

In this application there is a Login class which provides a login function to the application. Then there is the View Employee class which displays employee data. There is Add Employee class which provides add employee function by inputting employee name, department and shift. There is a Change Employee class which provides a change employee function with input of employee name, department and shift. There is an Employee Import class with excel file input. There is a Report class that provides a download link for the employee attendance report Excel file. There is an Absent which provides a Check In and Check Out attendance feature, there is an Absence History class that displays employee attendance data.

\subsection{Sequence Diagram}

The design of this application requirement is described in the Use Case Diagram.

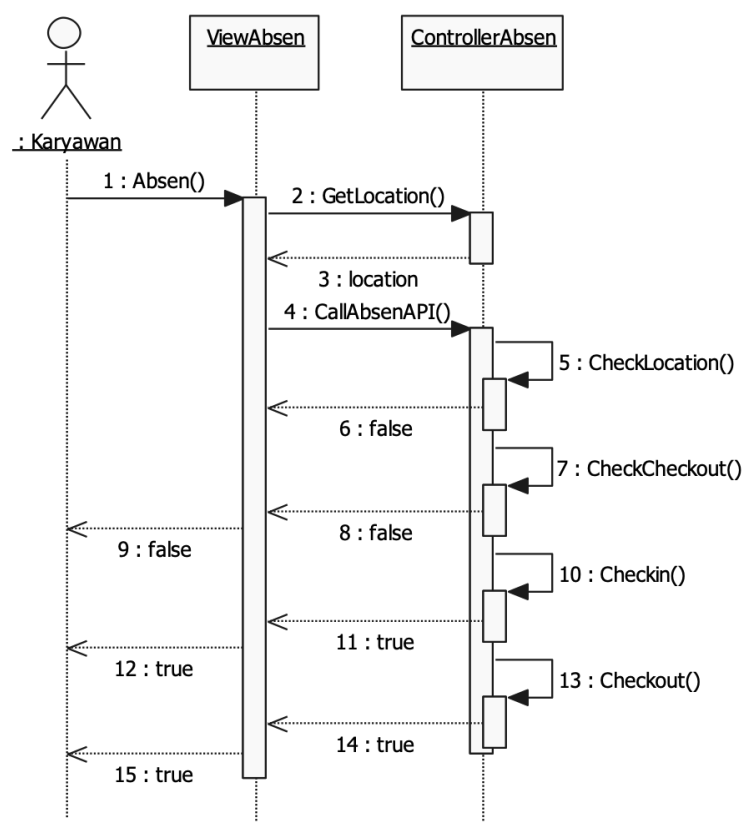

Fig 5. Sequence diagram.

In the attendance menu, employees press the Check In or Check Out button. Then the application will get the location coordinates of the employee's device. Then the application will access the absent API by sending the employee NIK and location coordinates. If the employee's position to the office is more than 500 meters, the application will issue a message "Distance exceeds 
the limit", and the attendance process fails. If the distance is less than 500 meters, then there is a check, whether the employee has checkout, if it is, the application will issue a message "You have checkout", and the attendance fails. Then if the employee has not checked in, the application will enter employee check-in data. If the employee has not checked out, the application will enter employee check out data.

\subsection{Result}

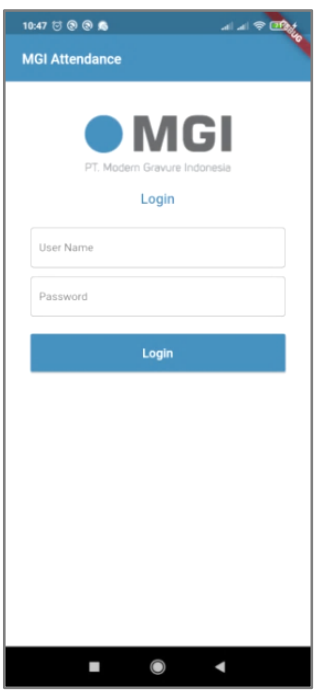

Fig 6. Login.

For login, admin or employee can enter their username and password.

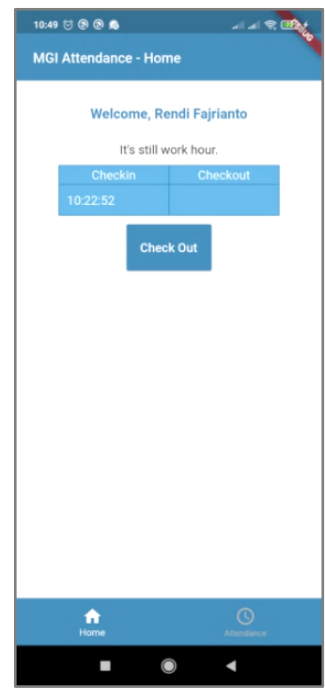

Fig 7. Attendance menu.

On the employee attendance page, there is an information table for Check In and Check Out hours. Then there is a Check In button if the employee has not checked in and checked out if the employee has not checked out, and if the employee has checked out, the button will disappear.

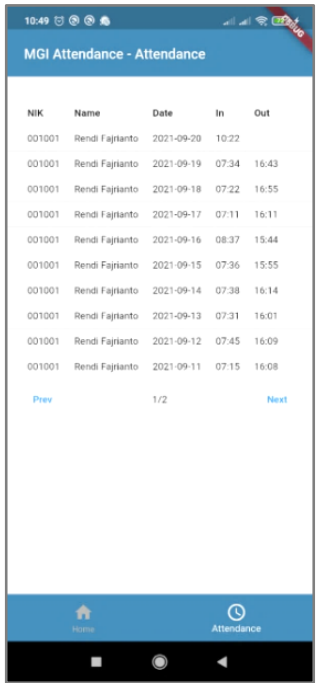

Fig 8. Attendance history.

On the Attendance History page, the employee's attendance information will appear which includes NIK, name, date of absence, time of entry and time of departure.

\subsection{Testing}

The test method in this application uses the Black Box testing method (Budiarto, 2020) is a software testing method where testing is carried out without knowing the structure of the program code (Vijay et al., 2018).

The following are the results of testing the Login feature using the Black Box method in the application.

Table 7. Testing login.

\begin{tabular}{|c|c|c|c|}
\hline No & Test Case & Remark & Result \\
\hline 1. & $\begin{array}{l}\text { Username: } \\
\text { empty } \\
\text { Password : } \\
\text { empty }\end{array}$ & $\begin{array}{l}\text { Login failed and the } \\
\text { application displays the } \\
\text { message "Username and } \\
\text { password are empty" }\end{array}$ & Valid \\
\hline 2. & $\begin{array}{l}\text { Username : } \\
\text { admin } \\
\text { Password : } \\
\text { empty }\end{array}$ & $\begin{array}{l}\text { Login failed and the } \\
\text { application displays the } \\
\text { message "Password is } \\
\text { empty" }\end{array}$ & Valid \\
\hline 3. & $\begin{array}{l}\text { Username : } \\
\text { empty } \\
\text { Password : } \\
123\end{array}$ & $\begin{array}{l}\text { Login failed and the } \\
\text { application displays the } \\
\text { message "Username is } \\
\text { empty" }\end{array}$ & Valid \\
\hline 4. & $\begin{array}{l}\text { Username : } \\
\text { admin } \\
\text { Password : } \\
123\end{array}$ & $\begin{array}{l}\text { Login failed and the app } \\
\text { displays the message } \\
\text { "Login failed" }\end{array}$ & Valid \\
\hline 5. & $\begin{array}{l}\text { Username : } \\
\text { admin } \\
\text { Password : } \\
123456\end{array}$ & $\begin{array}{l}\text { Login is successful and } \\
\text { the application displays } \\
\text { the admin page }\end{array}$ & Valid \\
\hline 6. & $\begin{array}{l}\text { Username : } \\
001001 \\
\text { Password : } \\
123456\end{array}$ & $\begin{array}{l}\text { Login is successful and } \\
\text { the application displays } \\
\text { the employee page }\end{array}$ & Valid \\
\hline
\end{tabular}

The following are the results of testing the Check In feature in the application. 
Table 8. Check in testing.

\begin{tabular}{clll}
\hline No & Test Case & \multicolumn{1}{c}{ Remark } & Result \\
\hline 1. & $\begin{array}{l}\text { Pressing the } \\
\text { Check In } \\
\text { button, } \\
\text { outside the } \\
\text { office }\end{array}$ & $\begin{array}{l}\text { Attendance failed and the } \\
\text { application displays the } \\
\text { message "Check In failed. } \\
\text { The distance between } \\
\text { your office and your } \\
\text { location is more than 500 } \\
\text { M, which is 1,399 M" }\end{array}$ & Valid \\
& & $\begin{array}{l}\text { Attendance is successful } \\
\text { and the application } \\
\text { displays the message } \\
\text { "Check In } \\
\text { button, at the } \\
\text { office }\end{array}$ & Valid \\
\hline
\end{tabular}

The following are the results of testing the Attendance History feature on the application.

Table 9.Attendance history testing.

\begin{tabular}{llll}
\hline No & Test Case & \multicolumn{1}{c}{ Remark } & Result \\
\hline 1. & $\begin{array}{l}\text { Press the } \\
\text { Attendance } \\
\text { history button }\end{array}$ & $\begin{array}{l}\text { The application displays } \\
\text { employee attendance } \\
\text { history for incoming and } \\
\text { outgoing hours }\end{array}$ & Valid \\
\hline 2. & $\begin{array}{l}\text { Pressing the } \\
\text { Export button }\end{array}$ & $\begin{array}{l}\text { Application displays } \\
\text { attendance history in } \\
\text { excel form }\end{array}$ & Valid \\
\hline
\end{tabular}

\section{CONCLUSION}

The result of this research is the Attendance Application with mobile-based LBS technology is already done and able to overcome long attendance queues and reduce the risk of exposure to Covid-19 at PT. Modern Gravure Indonesia. This application uses LBS technology so that it is able to retrieve employee location data so that absenteeism fraud does not occur.

\section{REFERENCES}

T. Masmur and Sandri Alfarisi, "Membangun Mobile Apps Job Order Berbasis Android Pada PT.Modern Gravure Indonesia," Membangun Mob. Apps Job Order Berbas. Android Pada PT.Modern Grav. Indones., vol. 17, no. 2, pp. 53-61, 2020.

S. Aji, "Infeksi Baru Covid di Semarang Diduga Lewat Alat Absensi," CNN Indonesia, 2020. .

R. Sri, Harini; Hafsan; Sahara; Isna, Rasdianah Aziz; Robbi, ICOST 2019: 1st International Conference on Science and Technology, ICOST 2019, 2-3 May, Makassar, Indonesia. Makasar: European Alliance for Innovation, 2020.

K. V. Jithesh, Sathyan; Anoop N; Navin, Narayan; Shibu, A Comprehensive Guide to Enterprise Mobility. London: CRS Press, 2016.

B. Alessandro, Flutter for Beginners : An Introductory Guide to Building Cross-platform Mobile Applications with Flutter and Dart 2. Birmingham: Packt Publishing, 2019.

M. K. Sigit Suryono, M Kom; Hardiansah, Falling In Love with Flutter Panduan Lengkap membuat aplikasi Android dan iOS dari Nol. Yogyakarta: PT. Lauwba Techno Indonesia, 2020.

A. R. Maulidyah, Buku Pintar Human Resources Development: Praktik Singkat Divisi Sumber Daya
Manusia. Sleman: Deepublish, 2019.

S. Leon A, Abdillah; Abdurrozzaq, Hasibuan; Sukarman, Purba; Dien,a Dwidienawati Tjiptadi; Eko, Sudarmanto; Ferdinando, Solissa; Aditya, Halim Perdana Kusuma Putra; Nina, Mistriani; Hengki, Mangiring Parulian Simarmata; Melda, Agnes Manuhutu; Salman, Human Capital Management. Medan: Yayasan Kita Menulis, 2020.

R. P. Putra, N. Puspitasari, and U. Mulawarman, "Aplikasi absensi perkuliahan berbasis android studi kasus absensi FKTI Universitas Mulawarman," Jurti, vol. 3, no. 1, pp. 47-54, 2019, [Online]. Available: http://ejournals.unmul.ac.id/index.php/INF/article/view/24 57.

J. A. Pribadi and N. Setiyawati, "AbsenLoc: Aplikasi Absensi Mobile Berbasis Lokasi AbsenLoc: Location-Based Mobile Attendance Application," vol. 09, no. 1, pp. 33-40, 2021, doi: 10.26418/justin.v9i1.41103.

A. Dayumi, and M. F. Mulya, "Sistem Abensi Karyawan Berbasis Location Based Services ( LBS ) Menggunakan Platform Android Studi Kasus : PT . Noxus Ideata Prima," vol. II, no. 1, 2018.

S. W. Charles, System Engineering Analysis, Design, and Development. New Jersey: John Wiley \& Sons Inc, 2015.

D. Ahmed, Sidky; Dayang Norhayati Abang, Jawawi; Imran, Ghani; Siva, Emerging Innovations in Agile Software Development. Pennsylvania: IGI Global, 2016.

U. Bhuvan, Software Engineering with UML. Boca Raton: CRC Press, 2017.

S. Ajit, Unified Modeling Language Simply In Depth. Morrisville: Lulu Press, 2019.

H. Raden Budiarto, Rekayasa Perangkat Lunak. Bantul: RBH, 2020.

D. Vijay, John; Harika, Principles and Practice of Software Testing. Shubham Vihar: Educreation Publishing, 2018.

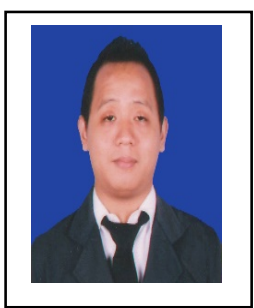

Rendi Fajrianto received the Associate Degree of Computer Science (A.Md. Kom) degree in Informatics Engineering from Batam State Polytechnic in 2016, and also as a Esa Unggul University student

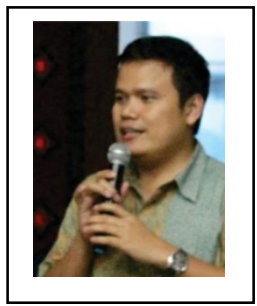

Masmur Tarigan received the Master of Computer Science (M.Kom) degree in Informatics Engineering from Universitas Budi Luhur in 2011, and also as a Esa Unggul University lecturer. 